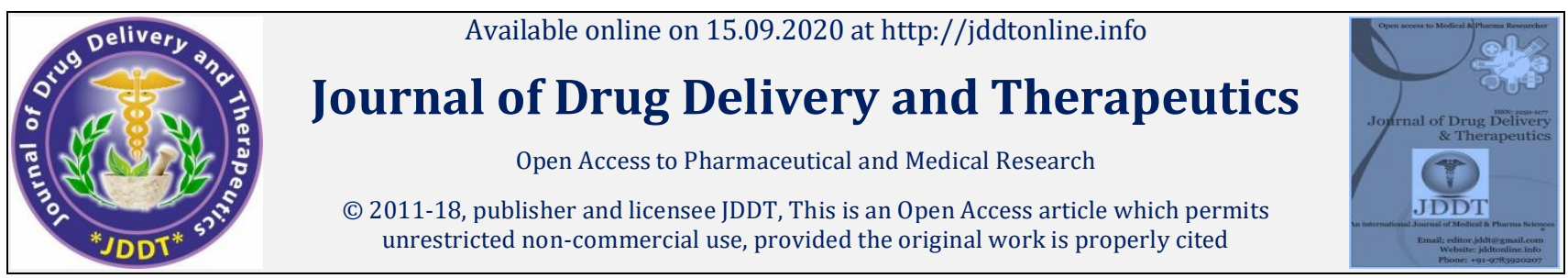

Open $\odot$ Access

Review Article

\title{
HING (Ferula foetida Regel): A potent Unani Herb with its descriptive parameters of pharmacognosy and pharmacology: A Review
}

\author{
Rasikh Javaid ${ }^{*}$, Ghazala Javed ${ }^{2}$, Raheela Javaid ${ }^{3}$, Anju ${ }^{4}$, Farah Ahmed5 ${ }^{\text {, Asim Ali Khan6 }}{ }^{6}$ \\ $1 \& 4$ Research Associate (Unani), Central Council for Research in Unani Medicine, Ministry of AYUSH, Govt. of India, New Delhi \\ ${ }^{2}$ Research Officer Unani, Scientist-4, Central Council for Research in Unani Medicine, Ministry of AYUSH, Govt. of India, New Delhi \\ ${ }^{3}$ Assistant Professor, Asian Institute of Medical Sciences, Unani Medical College, Zakura, Srinagar J\&K \\ ${ }^{5}$ Research Officer Unani, Central Council for Research in Unani Medicine, Ministry of AYUSH, Govt. of India, New Delhi \\ ${ }^{6}$ Director General, Central Council for Research in Unani Medicine, Ministry of AYUSH, Govt. of India, New Delhi
}

\begin{abstract}
Hing (Family- Umbelliferae) or asafoetida is the latex obtained from living rootstocks or taproots of several species of Ferula, e.g. F. alliacea Boiss, F. rubricaulis Boiss, F. assafoetida Linn and F. narthex Boiss found in central Asia. Asafoetida occurs in three forms, viz Tears, Mass and Paste. Hing has shown diverse biological and pharmacological activities. It has been used in Unani Medicine (Tibb-e-Unani) and other Traditional Systems of Medicine from time immemorial and it is described as diuretic, anti-diabetic, emmenagogue etc. The present review highlights the botanical description, traditional uses, pharmacognositcal features, pharmacological properties and pharmacological studies conducted on this Medicinal plant used in Unani system of medicine.
\end{abstract}

Keywords: Hing; Ferula foetida; Unani Medicine; Traditional Uses; Pharmacological Properties

Article Info: Received 08 July 2020; Review Completed 19 August 2020; Accepted 26 August 2020; Available online 15 Sep 2020

\section{Cite this article as:}

Javaid R, Javed G, Javaid R, Anju, Ahmed F, Khan AA, HING (Ferula foetida Regel): A potent Unani Herb with its descriptive parameters of pharmacognosy and pharmacology: A Review, Journal of Drug Delivery and Therapeutics. 2020; 10(5):362367 http://dx.doi.org/10.22270/jddt.v10i5.4372

*Address for Correspondence:

Dr. Rasikh Javaid, Research Associate (Unani), 506-Central Council for Research in Unani Medicine, Ministry of AYUSH, Govt. of India, New Delhi

\section{INTRODUCTION}

Hing (Family- Umbelliferae) is the latex obtained from living rootstocks or taproots of several species of Ferula, e.g. F. alliacea Boiss, F. rubricaulis Boiss, F. assafoetida Linn and F. narthex Boiss found in central Asia. Ferula asafoetida Linn. is a main source of Hing or asafoetida. It is an oleo-gum resin of medicinal and nutritional importance having a strong, tenacious and sulfurous odor. Asafoetida has been consumed as a spice and a folk medicine for centuries. Hing is a coarse umbelliferous plant growing up to 7 feet high, large fleshy root covered with bristly fibres, stem 6 to 10 feet, numerous stem leaves with wide sheathing petioles; flowers pale greeny yellow, fruit oval, flat thin, foliaceous, reddish brown with pronounced vittae, it has a milky juice and a strong foetid odour .Asafoetida occurs in three forms, viz Tears, Mass and Paste. The tears, $0.5-3 \mathrm{~cm}$ in size constituting the purest form of the resin, are rounded or flattened, $5-30 \mathrm{~mm}$ in diameter and greyish dull yellow in colour. Mass asafoetida is the common commercial form. It consists of tears agglutinated into a more or less uniform mass usually mixed with fragments of root, earth, etc. The paste form also contains extraneous matter. It is bitter in taste, yellowishwhite changing to reddish-brown in colour, and has intense, persistent, penetrating and alliaceous odour 1, 2, 3, 4, 5. It is mostly found in Afghanistan, Kashmir, Punjab, Iran, Turkistan and Pakistan 3,4,6.

\subsection{BOTANICAL DESCRIPTION}

It was first found in the sandy desert of Aral in 1844, but has been known since the twelfth century. Several species of Ferula yield asafoetida. The bulk of the drug comes from the official plant, which is indigenous to Afghanistan and grows from two to four thousand feet above sea level. These high plains are arid in winter but are thickly covered in summer with a luxuriant growth of these plants. The great cabbagelike folded heads are eaten raw by the natives. 


\subsection{Collection}

In the month of June the juice is collected from plants that are about four years old. The roots of plants which have not flowered are exposed and slashed, then shaded from the sun for five or six weeks and left for the gummy oleoresin to leak out and harden. It is then scraped off in reddish lumps and put into leather bags and sent to Herat, where it is adulterated before being placed on the market. A very fine variety of Asafetida is obtained from the leaf bud in the centre of the root and is only used in India, where it is known in the Bazaars as Kandaharre Hing. It appears in reddishyellow flakes and when squeezed gives out an oil 3, 4, 6.

\subsection{Adulteration}

Asafoetida is admittedly the most adulterated drug in the market. Besides being largely admixed with inferior qualities Asafetida is added with following things to increase the weight.

\subsection{Adulterants}

Gum Arabic, other gum resins, Rosin, Gypsum, Red clay, Chalk, Barely, Sand , Stones, Wheat flour, Slices of potatoes etc.

\subsection{IMPORTANT PROPERTIES OF HING AS PER UNANI SYSTEM OF MEDICINE}

Hing has shown diverse biological and pharmacological activities. It has been used in Unani Medicine (Tibb-e-Unani) and other Traditional Systems of Medicine from time immemorial.

\subsection{Pharmacological Actions (Table-A)}

The drug Hing (Ferula foetida Regel) is described in detail in ethnobotanical and classical Unani literature and various actions of the drug have been reported such as nervine stimulant, emmenagogue, carminative, anti-inflammatory, aphrodisiac, diuretic, antihelmintic, expectorant, laxative, antispasmodic, antidote, antiseptic, lithotriptic, analgesic, appetizer, abortifacient, astringent, demulcent, antipyretic, digestive, voice purifier ${ }^{1-15}$.

\section{1.2 Therapeutic Uses (Table-B)}

It is therapeutically used in various diseases such as paralysis, epilepsy, convulsions, tetanus, eye tonic, worm infestation, toothache, dry cough, jaundice, sciatica, arthritis, dysuria, ascites, flatulence, hysteria, asthma, colitis, abcess, ring worm, cataract, intestinal ulcer, fever, scorpion bite, tinnitus, hiccups, alopecia, cholera etc. 1-10, 12-14, 16, 17 .

\subsubsection{Mizaj (Temperament)}

\begin{tabular}{|c|c|}
\hline Mijaz & References \\
\hline Hot $^{4}$ and Dry ${ }^{2}$ & $11,12,13,15,14,1819$ \\
\hline Hot $^{3}$ and Dry ${ }^{2}$ & 11,20 \\
\hline Hot $^{2}$ and Dry ${ }^{2}$ & 9,18 \\
\hline Hot $^{4}$ and Dry 3 & 11,18 \\
\hline Hot $^{4}$ and Dry 4 & 10 \\
\hline Hot $^{3}$ and Dry ${ }^{3}$ & 11 \\
\hline
\end{tabular}

\subsubsection{Muzir Asaraat (Adverse Effects)}

\begin{tabular}{|l|l|}
\hline Adverse effect & References \\
\hline $\begin{array}{l}\text { Harmful to liver and brain in hot } \\
\text { temperament persons }\end{array}$ & 15,18 \\
\hline Harmful to liver and stomach & $10,13,18$ \\
\hline Harmful to liver & 9 \\
\hline Stomach & 12 \\
\hline
\end{tabular}

\subsubsection{Musleh (Correctives)}

\begin{tabular}{|l|l|}
\hline Musleh (Correctives) & References \\
\hline Anarain (Punica granatum) & 15,18 \\
\hline Anisoon (Pimpinella anisum) & 15,18 \\
\hline Kateera (Cochlospermum religiosum) & 15,18 \\
\hline Banafsha (Viola odorata) & 15,18 \\
\hline Nilofar (Nymphaea alba) & 15,18 \\
\hline Seb (Malus sylvestris) & 15 \\
\hline Sandal (Santalum album) & 15 \\
\hline Zarishk (Berberis vulgaris) & 9,18 \\
\hline Zeerah (Carum carvi) & 18 \\
\hline
\end{tabular}

\subsubsection{Badal (Substitute)}

\begin{tabular}{|l|l|}
\hline Badal (Substitute) & References \\
\hline Jaosheer (Ferula galbaniflua) & 15,18 \\
\hline Sakbeenaj (Ferula persica) & 15,18 \\
\hline Zeerah (Carum carvi) & 18 \\
\hline Tuhkm-e Gazar (Daucus carota) & 18 \\
\hline
\end{tabular}

\subsubsection{Miqdar-E-Khurak (Therapeutic Dose)}

\begin{tabular}{|l|l|}
\hline Miqdar -e- Khurak & References \\
\hline $0.5-1 \mathrm{gm}$ & 19 \\
\hline $1 \mathrm{gm}$ & 18 \\
\hline $1.75 \mathrm{gm}$ & 10 \\
\hline $1-2 \mathrm{gm}$ & 18 \\
\hline $2-2.25 \mathrm{gm}$ & 15 \\
\hline $3 \mathrm{gm}$ & 18 \\
\hline
\end{tabular}

\subsubsection{Mashhoor Murakkabat (Famous compound formulation)}

\begin{tabular}{|l|l|}
\hline Mashhoor Murakkab & Reference \\
\hline Sharbat Haft Roza & 21 \\
\hline Habbe-e-Halteet & 19 \\
\hline
\end{tabular}


Table-A: Afa'al (Pharmacological Actions)

\begin{tabular}{|c|c|c|}
\hline Actions & $\begin{array}{l}\text { Unani } \\
\text { Reference }\end{array}$ & $\begin{array}{l}\text { Ethno medical } \\
\text { References }\end{array}$ \\
\hline $\begin{array}{l}\text { Muharrik-e Aasab } \\
\text { (Nervine Stimulant) }\end{array}$ & 9,10 & $1,3,4,6,22$ \\
\hline $\begin{array}{l}\text { Mudir-e Haiz } \\
\text { (Emmenagogue ) }\end{array}$ & $\begin{array}{l}9,10,11,12, \\
13,14,15,19\end{array}$ & 1 \\
\hline $\begin{array}{l}\text { Kasir-e Riyah } \\
\text { (Carminative) }\end{array}$ & $\begin{array}{l}11,12,14,19, \\
20\end{array}$ & $\begin{array}{l}1,3,5,6,7,8, \\
22\end{array}$ \\
\hline $\begin{array}{l}\text { Muhallil } \\
\text { (Anti-inflammatory) }\end{array}$ & $9,13,19$ & - \\
\hline $\begin{array}{l}\text { Muqawwi-e Meda } \\
\text { (Stomachic) }\end{array}$ & 9,14 & 7 \\
\hline $\begin{array}{l}\text { Muqawwi-e Bah } \\
\text { (Aphrodisiac) }\end{array}$ & $\begin{array}{l}9,11,12,13, \\
14,15\end{array}$ & 1 \\
\hline $\begin{array}{l}\text { Mudir-e Baul } \\
\text { (Diuretic) }\end{array}$ & $\begin{array}{l}9,10,11,12, \\
13,14,19\end{array}$ & 1 \\
\hline $\begin{array}{l}\text { Qatile-Kirm } \\
\text { (Anthelmintic) }\end{array}$ & 9 & 1,22 \\
\hline $\begin{array}{l}\text { Munaffis } \\
\text { (Expectorant) }\end{array}$ & 14 & $1,4,5,8,22$ \\
\hline $\begin{array}{l}\text { Mulayyin } \\
\text { (Mild laxative) }\end{array}$ & 18 & $1,5,6,22$ \\
\hline $\begin{array}{l}\text { Dafa-e Tashannuj } \\
\text { (Antispasmodic) }\end{array}$ & 14,19 & $1,5,22$ \\
\hline $\begin{array}{l}\text { Fad-e Zehar } \\
\text { (Antidote) }\end{array}$ & $9,10,13$ & - \\
\hline $\begin{array}{l}\text { Dafa-e Taffun } \\
\text { (Antiseptic) }\end{array}$ & 14,19 & 1 \\
\hline $\begin{array}{l}\text { Mufattit-e Hisat } \\
\text { Gurda } \\
\text { (Lithotriptic) }\end{array}$ & 20 & - \\
\hline $\begin{array}{l}\text { Musakkin } \\
\text { (Analgesic) }\end{array}$ & $10,11,13,15$ & - \\
\hline $\begin{array}{l}\text { Mushtahi } \\
\text { (Appetizer) }\end{array}$ & - & 1 \\
\hline $\begin{array}{l}\text { Musaqqit } \\
\text { (Abortifacient) }\end{array}$ & 11,15 & 1 \\
\hline $\begin{array}{l}\text { Qabiz } \\
\text { (Astringent) }\end{array}$ & 10,13 & - \\
\hline Insecticidal & 10 & - \\
\hline $\begin{array}{l}\text { Muhmmir } \\
\text { (Rubefacient) }\end{array}$ & 14,19 & - \\
\hline Jali (Detergent) & 9 & - \\
\hline $\begin{array}{l}\text { Munawwim } \\
\text { (Sedative) }\end{array}$ & & 7 \\
\hline $\begin{array}{l}\text { Mufatteh } \\
\text { (Deobstruent) }\end{array}$ & 9 & - \\
\hline $\begin{array}{l}\text { Mulattif } \\
\text { (Demulcent) }\end{array}$ & 9 & - \\
\hline $\begin{array}{l}\text { Dafa-e Humma } \\
\text { (Fever) }\end{array}$ & 9 & - \\
\hline Hazim (Digestive) & 9,10 & - \\
\hline
\end{tabular}

Table-B: Mawaqe-Istemaal (Therapeutic Uses)

\begin{tabular}{|c|c|c|}
\hline Uses & $\begin{array}{l}\text { Unani } \\
\text { References }\end{array}$ & $\begin{array}{l}\text { Ethno medical } \\
\text { References }\end{array}$ \\
\hline $\begin{array}{l}\text { Faalij } \\
\text { (Paralysis) }\end{array}$ & $10-13,15,19,20$ & 1 \\
\hline $\begin{array}{l}\text { Sara } \\
\text { (Epilepsy) }\end{array}$ & $10-13,15$ & $1,4,5$ \\
\hline $\begin{array}{l}\text { Raasha } \\
\text { (Convulsions) }\end{array}$ & $11,15,20$ & - \\
\hline $\begin{array}{l}\text { Kuzaz } \\
\text { (Tetanus) }\end{array}$ & 10,15 & - \\
\hline $\begin{array}{l}\text { Muqawwi-e-Basr } \\
\text { (Eye tonic) }\end{array}$ & $10-13,15$ & - \\
\hline $\begin{array}{l}\text { Kirm-e Ama } \\
\text { (Worm infestation) }\end{array}$ & $10,15,21$ & 1 \\
\hline $\begin{array}{l}\text { Waja-ul Asnan } \\
\text { (Toothache) }\end{array}$ & $11-13,15,21$ & 1 \\
\hline $\begin{array}{l}\text { Suaal-e Yabis } \\
\text { (Dry cough) }\end{array}$ & $10-15,19$ & 1 \\
\hline $\begin{array}{l}\text { Musaffi awaz } \\
\text { (Voice purifier) }\end{array}$ & $10-13,15$ & - \\
\hline $\begin{array}{l}\text { Yarqan } \\
\text { (Jaundice) }\end{array}$ & $9,10,13,15$ & - \\
\hline $\begin{array}{l}\text { Irq-un-nasa } \\
\text { (Sciatica) }\end{array}$ & 9 & 1 \\
\hline $\begin{array}{l}\text { Wajaul Mafasil } \\
\text { (Arthritis) }\end{array}$ & 9,10 & - \\
\hline $\begin{array}{l}\text { Nisyan } \\
\text { (Dementia) }\end{array}$ & 9,19 & - \\
\hline $\begin{array}{l}\text { Usr-ul Baul } \\
\text { (Dysuria) }\end{array}$ & 9,19 & 1 \\
\hline $\begin{array}{l}\text { Istisqa } \\
\text { (Ascites) }\end{array}$ & 15 & - \\
\hline $\begin{array}{l}\text { Riyah } \\
\text { (Flatulence) }\end{array}$ & $11,12,14,19,20$ & $1,4,5,7,22$ \\
\hline $\begin{array}{l}\text { Ikhtinaq-ur-u } \\
\text { Reham } \\
\text { (Hysteria) }\end{array}$ & $14,19,21$ & 1 \\
\hline $\begin{array}{l}\text { Zeeq-un Nafas } \\
\text { (Bronchial Asthma) }\end{array}$ & 14,19 & $4,5,22$ \\
\hline $\begin{array}{l}\text { Qulanj } \\
\text { (Colitis) }\end{array}$ & 20,21 & - \\
\hline $\begin{array}{l}\text { Warme Luhat } \\
\text { (Uvulitis) }\end{array}$ & $10-13$ & - \\
\hline $\begin{array}{l}\text { Dabeela } \\
\text { (Abscess) }\end{array}$ & 13 & - \\
\hline $\begin{array}{l}\text { Quba } \\
\text { (Ring worm) }\end{array}$ & $10,12,13$ & 22 \\
\hline $\begin{array}{l}\text { Nazool-ul maa } \\
\text { (Cataract) }\end{array}$ & $10-13$ & - \\
\hline $\begin{array}{l}\text { Qurooh-e Ama } \\
\text { (Intestinal Ulcer) }\end{array}$ & 13 & 1 \\
\hline $\begin{array}{l}\text { Humma } \\
\text { (Fever) }\end{array}$ & $9,10,13$ & - \\
\hline $\begin{array}{l}\text { Gazedagiy-e Aqrab } \\
\text { (Scorpion bite) }\end{array}$ & $9,10,13$ & 1 \\
\hline $\begin{array}{l}\text { Tanin } \\
\text { (Tinnitus) }\end{array}$ & 11 & \\
\hline $\begin{array}{l}\text { Fuwwaq } \\
\text { (Hiccups) }\end{array}$ & 9,11 & - \\
\hline $\begin{array}{l}\text { Da-us- salab } \\
\text { (Alopecia) }\end{array}$ & 12 & - \\
\hline $\begin{array}{l}\text { Haiza } \\
\text { (Cholera) }\end{array}$ & & $1,4,5$ \\
\hline
\end{tabular}


Table-C: CHEMICAL CONSTITUENTS

\begin{tabular}{|l|l|}
\hline Chemical Constituents & References \\
\hline Essential oil & 23 \\
\hline Ferulic acid & 23 \\
\hline Organic sulphur & 23 \\
\hline Gum & 23 \\
\hline Resin & 23 \\
\hline Pinnene & 23 \\
\hline Organic disulphide & 23 \\
\hline Umbelliferone & 23 \\
\hline Asaresino-tannol & 1 \\
\hline Malic acid & 1 \\
\hline Resorcin & 1 \\
\hline Pyrocatachuic acid & 1 \\
\hline Umbellic acid & 3 \\
\hline Sec butyl propanyl disulphide & 3 \\
\hline Terpenes & 3 \\
\hline Vanillin & 5 \\
\hline Resene & 6 \\
\hline Luteolin & 24 \\
\hline Luteolin-7-0- $\beta$-D_glucopyranoside & 24 \\
\hline
\end{tabular}

\subsection{VARIOUS PHARMACOLOGICAL STUDIES CONDUCTED SO FAR WITH SOME RECENT DEVELOPMENTS}

On detailed search of the literature the following important pharamacological studies were found to be conducted on Hing (Ferula foetida Regel) so far. The details are as below-

\subsection{Anti-diabetic and Anti-hyperlipidemic Activities}

A study was conducted to investigate the hypoglycemic and hypolipidemic activity of ethanolic ferula asafoetida oleogum-resin extract (FAOGRETE) and also its effects on liver and kidney function in streptozotocin (STZ)-induced diabetic rats. The results of this study showed that FAOGRETE can regulate hyperglycemia and complications of diabetes. Antidiabetic and hypolipidimic activities of FAOGRETE are probably related to its antioxidant activity 25 .

\subsection{Transciptomic and Genetic study}

A 8-weeks feeding trial was conducted to examine the effects of different levels $(0,0.5,1$ and $2 \%)$ of dietary Ferula (Ferula assafoetida) on expression of antioxidant enzymes (GSR, GPX and GSTA), immune (TNF-alpha, IL1B, IL- 8 and LYZ) and growth (GH, IGF1 and Ghrl) genes as well as cutaneous mucus and serum non-specific immune response in common carp. The results revealed that Ferula significantly increased antioxidant gene expression (GSR and GSTA) in a dose dependent manner $(\mathrm{P}<0.05)$. The expression of immune and growth related genes were significantly higher in Ferula fed fish as compared to control group ( $\mathrm{P}<0.05)$. The effects of Ferula on expression of genes were more pronounced in higher doses. These results indicated up-regulation of growth and health related genes in Ferula fed common carp 26.

\subsection{Anti-Ulcer Activity}

A water based ultrasound mediated gel-phase dispersion of Asafoetida gum on fenugreek derived soluble galactomannan fibre matrix was employed. Micro-encapsulated particles (1 $\pm 0.3 \mu \mathrm{m}$ ) of asafoetida was prepared as water dispersible free flowing powder (Asafin). Fourier-transform infrared spectroscopy (FTIR), scanning electron microscopy (SEM), accelerated stability and in vitro dissolution studies confirmed the stability, sustained release and microencapsulated structure of Asafin. Further investigations revealed significant $(p<0.01)$ reduction in acetic acid-induced writhings and inhibition of ethanolinduced ulcer $(94.1 \%)$ in rats orally administered with Asafin at $250 \mathrm{mg} \mathrm{kg-1}$ b.w. Asafin also exhibited antiinflammatory effects $(\mathrm{p}<0.01)$, in acute and chronic paw edema mice models. The safety of Asafin was further demonstrated by acute toxicity studies at $4 \mathrm{~g} \mathrm{~kg}-1$ b.w. and by 28 days of sub-acute toxicity studies at $2.0 \mathrm{~g} \mathrm{~kg}-1$ b.w. ${ }^{27}$

\subsection{Cytotoxicity and anticonvulsant activity}

Cytotoxicity and anticonvulsant activity of the methanol extracts from several Ferula species were evaluated. For determination of the cytotoxicity of the extracts the oleogum-resin of $F$. assafoetida L., the brine shrimp (Artemia salina) was employed as a model assay system since it provides a convenient in-house pre-screening method for evaluating general cytotoxicity. The methanol extracts of different Ferula species and the oleo-gum-resin of $F$. assafoetida exhibited cytotoxic effect with LC50 values in the range of 6-321 $\mu \mathrm{g} / \mathrm{mL}$. For the anticonvulsant testing, seizure was induced by injection of pentylenetetrazole (PTZ), $90 \mathrm{mg} / \mathrm{kg}$ intraperitoneally (i.p.). All of the extracts and the oleo-gum resin of $F$. asafoetida showed dose-dependent cytotoxicity while methanol extracts and F. asafoetida oleogum resin did not possess anticonvulsant activity ${ }^{28}$.

\subsection{Anti-parasitic activity}

The effect of $F$. asafoetida on Schistosoma mansoni in experimentally infected mice was investigated. F. asafoetida was given orally via intragastric tube in an oil-form and a powder-form in different concentrations. A highly significant statistical difference between the test groups was recorded in comparison to the infection control. The highest reduction in worm burden and egg counts was found with powder form of $\boldsymbol{F}$. asafoetida (Gs III \& IV) when compared to oil form as confirmed histopathologically and by ultrastructural profile alteration 29 .

\subsection{Pregnancy interceptive property}

Ethanolic extract of Ferula assafoetida and chloroform fraction of Melia azedarach, both devoid of estrogenic activity, were examined for their pregnancy interceptive property. Treatment of rats from days 1 to 7 of pregnancy with either of the plant extracts resulted in pregnancy failure in about $65-85 \%$ of the animals. The possible role of energy metabolism in the antifertility action was investigated by measuring changes in activities of the key enzymes of carbohydrate metabolism in uterus on day 7 of pregnancy. It was observed that on the day 7 of pregnancy, one key enzyme of glycolytic pathway (phosphofructokinase) was significantly reduced in the uteri of treated rats as compared to controls. It was thus concluded that plants lacking phytoestrogens may intercept pregnancy by their ability to disrupt energy metabolism in rat uterus during implantation, especially the oxidative pathway ${ }^{30}$.

\subsection{Antispasmodic and hypotensive activity}

The effects of Ferula foetida gum extract on the contractile responses of isolated guinea-pig ileum induced by acetylcholine, histamine and $\mathrm{KCl}$ and on the mean arterial blood pressure of rat were investigated. Exposure of the precontracted ileum by acetylcholine (10 microM) to Ferula asafoetida gum extract caused relaxation in a concentrationdependent manner. Similar relaxatory effect of the extract was observed on the precontracted ileum by histamine $(10$ microM) and $\mathrm{KCl}(28 \mathrm{mM})$. However, when the preparations 
were preincubated with indomethacin $(100 \mathrm{nM})$ and different antagonists, such as propranolol (1 microM), atropine $(100 \mathrm{nM})$, and chlorpheniramine $(25 \mathrm{nM})$ then were contracted with $\mathrm{KCl}$, exposure to the extract $(3 \mathrm{mg} / \mathrm{ml})$ did not cause any relaxation. Furthermore, Ferula asafoetida gum extract (0.3-2.2 mg/100g body weight) significantly reduced the mean arterial blood pressure in anaesthetised rats. It might be concluded that the relaxant compounds in Ferula asafoetida gum extract interfere with a variety of muscarinic, adrenergic and histaminic receptor activities or with the mobilisation of calcium ions required for smooth muscle contraction non-specifically 31 .

\subsection{Anti-Hypertensive Activity:}

The present study was designed to evaluate the effects of hydroalcoholic extract of the stems of $F$. foetida in dexamethasone (Dex)-induced hypertension in rats. Hypertension was induced by subcutaneous injection of Dex $(30 \mu \mathrm{g} / \mathrm{kg})$ for 14 days. In a prevention study, rats received oral $F$. foetida extract $(200,400$ and $800 \mathrm{mg} / \mathrm{kg}$ ) for 4 days prior to Dex administration and during the test period (Days 1-18). Dex-induced hypertensive rats showed significant increases in SBP and in plasma $\mathrm{H}_{2} \mathrm{O}_{2}$ and decreases in the body and thymus weights and in Fluorescence recovery after photobleaching (FRAP) value $(\mathrm{P}<0.001)$. Administration of $F$. foetida extract significantly prevented and reversed hypertension at all doses. These results suggest antihypertensive and antioxidant effects of $F$. foetida stem extract in Dex-induced hypertension ${ }^{32}$.

\subsection{Anti-fungal activity}

The effect of Asafoetida on growth of Trichomonas vaginalis in vitro was studied and compared to metronidazole as a reference drug. It showed that Asafoetida had a potent antiparasitic effect on $T$. vaginalis compared to metronidazole, thus, worth further investigation to study its applicability in treatment of parasitic infections ${ }^{33}$.

\subsection{Chemo-preventive effect}

A study was conducted to ascertain the modulatory influences of Ferula asafoetida L. on the mammary epithelial tissue differentiation, hepatic drug metabolizing enzymes, antioxidant profiles and $\mathrm{N}$-methyl-N-nitrosourea (MNU)induced mammary carcinogenesis in Sprague-Dawley rats. Feeding with two doses of asafoetida ( 1.25 and $2.5 \% \mathrm{w} / \mathrm{w}$ in diet) showed a remarkable increase in the development and differentiation of ducts/ductules ( $p<0.01-0.005)$, lobules ( $p$ $<0.005$ ) and a decrease in terminal end buds ( $p<0.05$ 0.005 ) as compared to both normal and MNU-treated control animals ${ }^{34}$.

\subsection{Antioxidant activities}

3.11.1 The antioxidant and anticarcinogenic potential of asafoetida (Ferula narthex) in swiss albino mice was evaluated. It was found that asafoetida is a potent antioxidant and can afford protection against free radical mediated diseases such as carcinogenesis ${ }^{35}$.

3.11.2 The study was designed to examine antioxidant and antihaemolytic activities of Ferula foetida regel flower, stem and leaf extracts and it showed remarkable antioxidant and antihemolytic activities. Biological effects may be attributed to the presence of phenols and flavonoids in the extract. It is very promising for further biochemical experiments ${ }^{36}$.

3.11.3 Identifion of the chemical compounds and evaluation of various antoxidative activities of Ferulaassa-foetida leaves hydroalcoholic extract (FLHE) and Ferula-assa-foetida leaves essential oil (FLEO) was carried out. In FLHE and FLEO, total antioxidant capacity were $1.55 \pm 0.13$ and $1.09 \pm 0.43 \mathrm{nmol}$, ascorbic acid equivalents/g, phenol content were $441.37 \pm 2.50$ and $76.56 \pm 9.65 \mathrm{mg}$ of Gallic acid equivalents (GAE)/g, and flavonoid content was 12.53 \pm 3.20 and $0.015 \pm 0.002 \mathrm{mg}$ of quercetin equivalents/100 g respectively. This study showed that Ferula-assa-foetida has good antioxidant properties ${ }^{37}$.

\subsection{Anti-microbial, Antioxidant, and Anti-Inflammatory} Activities

Antimicrobial, antioxidant, and anti-inflammatory activities of the essential oils of 18 plant species from Tajikistan (Central Asia) were investigated. The essential oils of these aromatic plants including Ferula assa-foetida showed antimicrobial, antioxidant, and anti-inflammatory activities 38 .

\subsection{Anti-haemolytic Activity}

The study was designed to examine antioxidant and antihaemolytic activities of Ferula foetida regel flower, stem and leaf extracts and it showed remarkable antioxidant and antihemolytic activities in Ferula foetida. Biological effects may be attributed to the presence of phenols and flavonoids in the extract. It is very promising for further biochemical experiments ${ }^{36}$.

\subsection{Acute and subchronic toxicity Studies}

A study was performed to investigate acute and subchronic oral toxicity of Ferula assa-foetida gum (28 days) in Sprague Dawley rats. The obtained data revealed that oral administration of $F$. assa-foetida extract in rats for 28 successive days had no significant changes on body weight, and hematological parameters in rats all duringthe period of the experiment, and there were no significant increases in the activity of aspartate aminotransferase, alanine aminotransferase, alkaline phosphatase, creatinine and urea. Liver of treated rats showed mild changes as thrombosis and sinusoidal leukocytosis. It also showed portal infiltration with inflammatory cells, while kidney of treated rat showed an atrophy of glomerular tuft, thickening of parietal layer of Bowman capsule, and focal tubular necrosis. It also showed dilatation and congestion of renal blood vessels. Therefore $F$. assa-foetida gum had broad safety and little toxicity for short term use in dose of $250 \mathrm{mg} / \mathrm{kg}$. 39 .

\subsection{Nephro-Protective Activity}

The study validated the nephroprotective effects of Hing (Ferula foetida) extracts on gentamicin-treated rats. The subcutaneous administration of rats with Gentamicin (100 $\mathrm{mg} / \mathrm{kg}$ ) showed significant increase in blood urea nitrogen (BUN), serum creatinine and thiobarbituric acid reacting substances (TBARS), as an indication of renal disorder. However, co-administration of methanol soluble and insoluble fractions of Ferula foetida, to the Gentamicintreated rats almost showed a complete reversal of the above effects, indicating nephroprotective properties of the herbal drug 40 .

\subsection{Other Biological Activities}

Recent studies have shown several promising activities particularly relaxant, neuroprotective, memory enhancing, digestive enzyme, antioxidant, antispasmodic, hypotensive, hepatoprotective, antimicrobial, anticarcinogenic, anticancer, anticytotoxicity, antiobesity, anthelmintic and antagonistic effect ${ }^{41}$. 


\subsection{CONCLUSION}

Hing has been in use since times immemorial in Unani medicine as wekll as other traditional systems of medicine to treat wide range of ailments. It has been subjected to quite extensive Phytochemical, experimental and clinical investigations. Experimental studies have demonstrated diverse biological and pharmacological activitieswhich include antioxidant, Fibrinolytic, Chemo preventive, Antifungal, Nephro-protective, Anti-microbial, Anti-convalescent, Anti-Parasitic, antihyperlipidemic and antidiabetic activities. The scientific studies have substantiated the claims of traditional systems of medicine. However, further detailed clinical research appears to be worthwhile to explore the full therapeutic potential of this drug.

\section{Funding Agency: Nil}

\section{REFERENCES:}

1. Nadkarni K.M. Indian Materia Medica. Bombay Popular Prakashan, Bombay, Vol. I , 328-30; 1989.

2. Kirtikar K.R, Basu B.D. Indian Medicinal Plant Second Edt. Vol. III ;1214-17. International Book Distributors, Rajpur Road, Dehradun, 1996

3. Kokate C.K., Purohit A.P., Gokhale S.B. Pharmacognosy. Nirali Prakashan; 342-44. (2003)

4. Anonymous. The Wealth of India (Raw Materials). Vol. 1, F-G: 20-21, Publications \& Information Directorate, Council of Scietific \& Industrial Research (CSIR), New Delhi; 1956.

5. Ali M. Pharamacognosy (Pharmacognosy \& Phytochemistry). Vol. I. CBS Publishers and Distributors New Delhi; 2008.

6. Wallis T.E. Text Book of Pharmacognosy. $5^{\text {th }}$ edition CBS publishers \&distributors New Delhi; 1985

7. Shah C.H., Qadry J.S. Text Book of Pharmacognosy. B.S.Shah Prakashan Ahmedabad. 1992-93

8. Trease and Evans "Pharmacognosy" W.B. Saunders, Edinburgh, Tokyo ;2002

9. Khan, A. Muheetul Azam. Dar Matba Nizami Waqah Kanpur; 211-212; $1303 \mathrm{H}$.

10. Ibn-e-Baitar. Aljamiul Mufradat Al Advia Wal Aghzia (Urdu). Vol. III ; 170-73,CCRUM, New Delhi; 1999.

11. Ghani, M. Khazain-ul-Advia. Sheikh Basheer Ahmad \& Sons, Lahore, Pakistan, 1920

12. Baghdadi M.A.A.H. Kitab-ul-Mukhtarat fit-Tib. CCRUM New Delhi; 2005.

13. Ibn-e-Sina. Alqanoon Fit Tibb (Urdu translation by Ghulam Hasnain Kantoori) Vol.II; 159-63; Sheikh Mohammad Bashir \& sons, Lahore; 1927

14. Kabiruddin M. Makhzanul Mufradat. Sheikh Mohammad Bashir \& Sons, Lahore, Pakistan; 1951

15. Hakim, M.A. H. Bustanul Mufradat. Idara Taraqqi Urdu wa Publications, Lucknow, 1311

16. Ghani M.N. Khazain-ul-Advia. Translation by CCRUM, Vol. VI, New India Offset Printers, New Delhi, 2010

17. Hakim, M.A. Bustan-ul Mufradat, CCRUM, New Delhi, Ajaz Publications, New Delhi Urdu, 2011

18. Ghani, M.N. Khawasul Advia. Vol-I, Kashmiri Bazar, Rawalpindi, Lahore, 1911.

19. Lubhaya, R.H, Goswami Bayanul Advia. Goswami Pharmacy, Gali Qasim Jan Delhi. (1984),

20. Alqamari, A.M.H.I.N. Riyazul Advia. Dar Matba Muhammadi; 1272.

21. Multani, H.C. Dr. H. Tajul Aqaqeer Hindustan Ki Jadi Buteeyan. vol II, Nirla Pub.;1964.

22. Kirtikar, K.R., Basu, B.D. (1988) "Indian Medicinal Plants" International Book Distributors, Rajpur Road, Dehradun, Second Edt. Vol. III p-1214-17

23. Chopra, R.N., Nayar, S.L., Chopra, I.C. Glossary of Indian Medicinal Plants. Directorate, Council of Scietific \& Industrial Research (CSIR), New Delhi; 1956

24. Rastogi, R.P. and Mehrotra, B.N. "Compendium of Indian Medicinal Plants" Vol. I, (1970 1979), p-183; Central Drug
Research Institute, Lucknow and Publication \& Information Directorate, New Delhi, India, (1993)

25. Ebrahim Latifia, Ahmad Ali Mohammadpour, Behrooz Fathi H, Hosein Nourani. Antidiabetic and antihyperlipidemic effects of ethanolic Ferula assa-foetida oleo-gum-resin extract in streptozotocin-induced diabetic wistar rats. Biomedicine \& Pharmacotherapy. 2019; 110:197-202

26. Roghieh Safari, Seyed Hossein Hoseinifar, Shabnam Nejadmoghadam, Ali Jafar Transciptomic study of mucosal immune, antioxidant and growth related genes and nonspecific immune response of common carp (Cyprinus carpio) fed dietary Ferula (Ferula assafoetida). Fish \& Shellfish Immunology, 2016; 55:242-248

27. Liju Vijayasteltar, I.J. Jismy, Ashil Joseph, Balu Maliakel, Ramadasan Kuttan, Krishnakumar I.M. Beyond the flavor: A green formulation of Ferula asafoetida oleo-gum-resin with fenugreek dietary fibre and its gut health potential. Toxicology Reports 2017; 4:382-390

28. Seyyed Majid Bagheri, Amirhossein Sahebkar, Ahmad Reza Gohari, Soodabeh Saeidnia, Maryam Malmir \& Mehrdad Iranshahi. Evaluation of cytotoxicity and anticonvulsant activity of some Iranian medicinal Ferula species. Journal of Pharmaceutical Biology, 2016; 48(3):242-246

29. Ramadan N.I., Abdel-Aaty H.E., Abdel-Hameed D.M., E.l. Deeb H.K., Samir N.A., Mansy S.S., Al Khadrawy F.M. Effect of Ferula assafoetida on experimental murine Schistosoma mansoni infection. J Egypt Soc Parasitol. 2004; 34

30. Keshri G, Bajpai M. Interceptive action of Ferula assafoetida and Melia azedarach extracts in rat. Contraception. 2004; 70(5):429-32

31. Fatehi M, Farifteh F, Fatehi-Hassanabad Z. Antispasmodic and hypotensive effects of Ferula asafoetida gum extract. $J$ Ethnopharmacol. 2004; 91(2-3):321-4.

32. Leila Safaeian, Alireza Ghannadi, Shaghayegh Haghjoo Javanmard, Mohammad Hadi Vahidian. The effect of hydroalcoholic extract of Ferula foetida stems on blood pressure and oxidative stress in dexamethasone-induced hypertensive rats. Res. Pharm Sci.; 2015; 10(4):326-334

33. Ramadan N.I., Al Khadrawy F.M. The in vitro effect of Assafoetida on Trichomonas vaginalis: J Egypt Soc Parasitol. 2003; 33(2):615-30.

34. Mallikarjuna G.U., Dhanalakshmi S., Raisuddin S., Rao A.R. Chemomodulatory influence of Ferula asafoetida on mammary epithelial differentiation, hepatic drug metabolizing enzymes, antioxidant profiles and N-methyl-N-nitrosourea-induced mammary carcinogenesis in rats. Breast Cancer Res Treat. 2003; 81(1): 1-10

35. Saleem M, Alam A, Sultana S. Asafoetida inhibits early events of carcinogenesis: A Chemopreventive Study. Life Sci. 2001; 68(16):1913-21.

36. Nabavi S.M., Ebrahimzadeh M. A., Nabavi S. F., Eslami B., Dehpour A.A. Antioxidant and antihaemolytic activities of Ferula foetida Regel (Umbelliferae). European Review for Medical and Pharmacological Sciences, 2011; 15(2):157-164

37. Hassan Ahmadvand, Hamze Amiri, Zahra Dehghani Elmi, Shahrokh Bagheri. Chemical Composition and Antioxidant Properties of Ferula-assa-foetida Leaves Essential Oil. Iranian Journal of Pharmacology and Therapeutics, Iran University of Medical Sciences. 2014; 12(2):52-57

38. Farukh Sharopov, Markus Santhosh Braun, Isomiddin Gulmurodov, Davlat Khalifaev, Salomiddin Isupov, Michael Wink. Antimicrobial, Antioxidant, and Anti-Inflammatory Activities of Essential Oils of Selected Aromatic Plants from Tajikistan. Foods. 2015; 4(4):645-653

39. Ayman Goudah, Khaled Abdo-El-Sooud, Manal A. Yousef. Acute and subchronic toxicity assessment model of Ferula assafoetida gum in rodents. Vet World. 2015; 8(5):584-589.

40. Rasikh Javaid, Mohd Aslam, Raheela Javaid, Qudsia Nizami, Kalim Javed and M.U. Azhar. Extract of Ferula foetida regel reverses gentamicin-induced nephrotoxicity in rats. EXCLI J. 2012; 11:760-766

41. Augustine Amalraj, Sreeraj Gopi. Biological activities and medicinal properties of Asafoetida: A review. Journal of Traditional and Complementary Medicine. 2017; 7(3):347-359 